\title{
Abses pada gajah sumatera (Elephas maximus sumatranus)
}

\author{
Hamdan Ubaidillah ${ }^{1}$, Niluh Selly Frantika ${ }^{2}$, Laily Purnamasari ${ }^{3}$, Mokhamad Fakhrul Ulum ${ }^{4} *$ \\ ${ }^{1}$ Program Pendidikan Profesi Dokter Hewan, Fakultas Kedokteran Hewan, Institut Pertanian Bogor, Jawa Barat \\ ${ }^{2}$ Program Pendidikan Profesi Dokter Hewan, Fakultas Kedokteran Hewan, Universitas Airlangga, Jawa Timur \\ ${ }^{3}$ Maharani Zoo dan Goa, Lamongan, Jawa Timur \\ ${ }^{4}$ Departemen Klinik, Reproduksi, dan Patologi, Fakultas Kedokteran Hewan, Institut Pertanian Bogor, Jawa Barat
}

ABSTRAK: Abses merupakan kasus yang sering terjadi pada jaringan kulit gajah. Seekor gajah Sumatera dewasa mengalami
kebengkakan pada jaringan otot di sekitar tuber ischii, sedangkan anak gajah mengalami kebengkakan di daerah sekitar
vagina. Gajah dikekang dan ditangani oleh keeper menggunakan tali dan rantai. Jaringan kulit daerah bengkak pada gajah
Sumatra dewasa dan anak gajah disayat dan ditemukan adanya akumulasi nanah. Terapi yang diberikan pada kedua gajah
yaitu pembersihan luka menggunakan $3 \% \mathrm{H}_{2} \mathrm{O}_{2}$ dilanjutkan dengan pemberian iodine dan pemberian antibiotik topikal. Terapi
pada kedua gajah dilakukan setiap hari sekali selama kurang lebih 2 minggu. Persembuhan pascaterapi berupa pengurangan
kebengkakan dan tampak luka yang mengering.
Kata kunci:
abses, gajah sumatera

\section{- PENDAHULUAN}

Gajah merupakan hewan mamalia deangan kulit yang tebal dan keras. Ketebalan kulit gajah berkisar antara $2.5-5 \mathrm{~cm}$. Luka pada kulit sering terjadi pada gajah yang telah didomestikasi (Sukklad et al. 2006). Trauma mekanik benda tajam seperti alat pemukul (handling) gajah milik pawang, potongan kayu tajam serta ikatan rantai yang terlalu kuat merupakan beberapa penyebab terjadinya luka. Selain itu, di alam liar tubuh gajah yang besar juga menjadi faktor predisposisi terjadinya luka pada kulit gajah.

Gajah adalah hewan yang memiliki struktur jaringan kulit yang unik. Barman et al. (2013) menyatakan bahwa jaringan kulit gajah tidak memiliki kelenjar sebaseus. Hal tersebut menyebabkan kulit gajah menjadi kering, sehingga di habitat alaminya gajah sering berendam serta menyemprotkan lumpur pada tubuhnya untuk melindungi tubuhnya dari radiasi sinar ultraviolet. Patogen dipermukaan kulit gajah mudah berkembang ketika kulit dalam kondisi sangat kering. Jika terdapat luka pada kulit gajah, maka luka dengan mudah mengalami infeksi. Infeksi pada kulit yang luka akan membentuk jaringan abses.

\section{- KASUS}

Kasus pertama. Anamnesis: Seekor gajah sumatera di Maharani Zoo dan Goa Lamongan Jawa Timur mengalami kebengkakan pada jaringan otot sekitar tuber ischii (Gambar 1a,b). Sinyalemen: Gajah betina bernama Mayang. Temuan klinis: Ketika dilakukan penyayatan ditemukan adanya akumulasi nanah pada jaringan. Pemeriksaan klinis: Gajah mengalami abses. Prognosa: Fausta. Tindakan/terapi: Penyayatan luka dilanjutkan dengan pembersihan (flushing) jaringan yang mengalami abses, flushing menggunakan $3 \% \mathrm{H}_{2} \mathrm{O}_{2}$ dan cairan iodine serta pemberian antibiotik topikal.

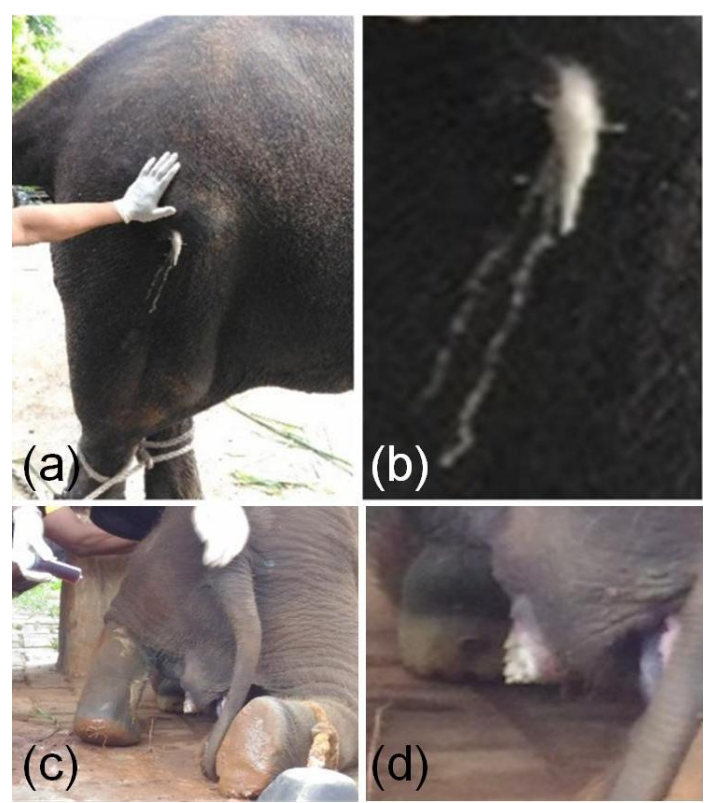

Gambar 1. Proses flushing menggunakan $3 \% \mathrm{H}_{2} \mathrm{O}_{2}$ pada gajah sumatera dewasa (a,b) dan proses flushing iodine pada anak gajah (c,d).

Kasus kedua. Anamnesis: Seekor anak gajah sumatera di Maharani Zoo dan Goa Lamongan Jawa Timur mengalami kebengkakan pada jaringan daerah vulva (Gambar 1c,d).

Diterima: 21-05-2018 | Direvisi: 03-06-2018 | Disetujui: 30-06-2018 (C) 2018 CC-BY-SA. Ini adalah artikel Open Access yang didistribusikan berdasarkan ketentuan dari Creative Commons Attribution ShareAlike 4.0 International License (https://creativecommons.org/licenses/by-sa/4.0/). 
Sinyalemen: Anak gajah sumatera betina, berumur 4 bulan, bernama Rani. Temuan klinis: Ditemukan akumulasi nanah pada jaringan. Pemeriksaan klinis: Gajah mengalami abses. Prognosa: Fausta. Tindakan/terapi: Pembersihan (flushing) jaringan yang mengalami abses, flushing menggunakan $3 \% \quad \mathrm{H}_{2} \mathrm{O}_{2}$ dan cairan iodine serta pemberian antibiotik topikal.

\section{- HASIL DAN PEMBAHASAN}

Pengekangan dilakukan terlebih dahulu pada kedua gajah dengan mengikat kaki depan dan belakang menggunakan rantai atau tali khusus sebelum terapi (Gambar 1). Hal tersebut dilakukan agar gajah tidak memberontak saat terapi berlangsung. Selama terapi, keeper atau pawang gajah selalu mendampingi untuk menjaga terhadap hal yang tidak diinginkan, seperti kaburnya gajah dan lain sebagainya

Jaringan abses pada gajah dewasa dan anak gajah terlebih dahulu dibersihkan menggunakan cairan $3 \% \mathrm{H}_{2} \mathrm{O}_{2}$. Flushing dilakukan menggunakan spoit ukuran $25 \mathrm{ml}$. Ujung spoit dimasukkan kedalam lubang pada jaringan abses, selanjutnya cairan disemprotkan dengan kuat. Jaringan kemudian ditekan untuk mengeluarkan nanah (Gambar 1). Flushing 3\% $\mathrm{H}_{2} \mathrm{O}_{2}$ dilakukan sekali sehari, sebanyak 3-4 kali semprotan. Menurut Setiawan et al. (2013), $\mathrm{H}_{2} \mathrm{O}_{2}$ ketika berkontak dengan jaringan abses akan terjadi reaksi $\mathrm{H} 2 \mathrm{O} 2$ $+\mathrm{OH} \rightarrow \mathrm{H}+\mathrm{O}_{2}+\mathrm{H} 2 \mathrm{O}$. Ion $\mathrm{H}^{+}$terbentuk setelah reaksi menyebabkan $\mathrm{pH}$ jaringan menjadi asam. Perubahan $\mathrm{pH}$ serta terbentuknya molekul $\mathrm{O}_{2}$ dapat membunuh bakteri anaerob penyebab abses. Selain itu, air $\left(\mathrm{H}_{2} \mathrm{O}\right)$ yang terbentuk setelah reaksi juga berfungsi sebagai pembersih jaringan. Setiawan et al. (2013) mengatakan bahwa hidrogen peroksida merupakan antiseptik yang efektif dan tidak toksik, sehingga sangat baik digunakan sebagai pembersih luka maupun jaringan abses. Tindakan selanjutnya pada gajah dewasa yaitu flushing jaringan menggunakan cairan iodine dengan metode yang sama seperti flushing $3 \% \quad \mathrm{H}_{2} \mathrm{O}_{2}$. Sedangkan pada anak gajah penyemprotan dilakukan dengan tekanan yang lebih lemah, karena anak gajah sulit untuk diam saat proses terapi.

Antibiotik sebagai terapi terakhir pada kedua gajah. Antibiotik topikal Limoxin spray (Netherland) bertujuan untuk membunuh bakteri penyebab abses. Limoxin spray juga mencegah lalat untuk mendekati dan menempelkan telur atau larva pada jaringan abses. Zat aktif dalam Limoxin spray yaitu oksitetrasiklin (Interchemie 2017).

Durasi terapi pada gajah yang mengalami abses cukup beragam, bergantung pada penyebab abses, lingkungan, tempat abses dan status nutrisi gajah (Sukklad et al. 2006). Terapi abses pada anak gajah dan gajah dewasa dilakukan kurang lebih selama 2 minggu. Hal tersebut sesuai dengan Basha et al. (2016) bahwa kebengkakan pada abses akan mengalami penurunan dengan pemberian terapi berturut- turut selama 15 hari. Terapi selama 14 hari memberikan tingkat kesembuhan yang baik (Gambar 2).

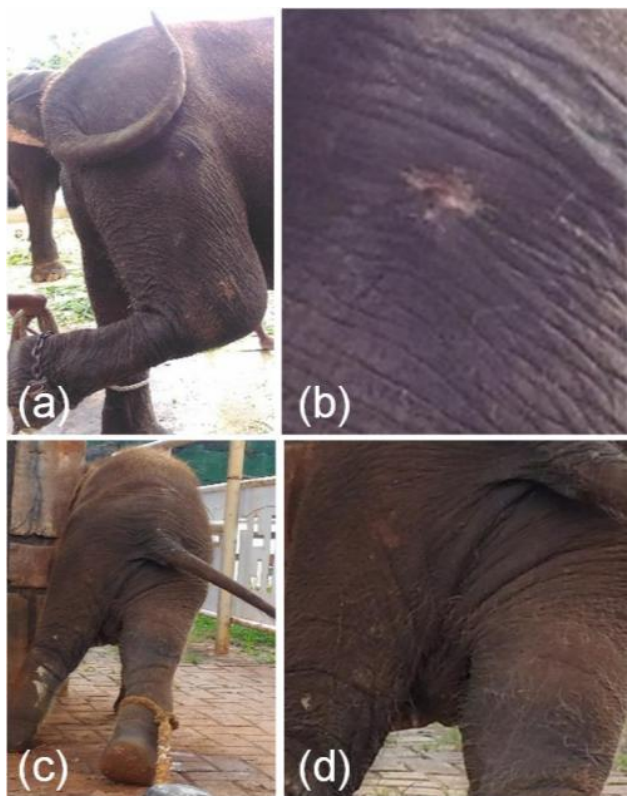

Gambar 2. Abses yang telah mengempis dan mengering pascaterapi pada gajah sumatera dewasa $(a, b)$ dan anak gajah $(\mathrm{c}, \mathrm{d})$

\section{- SIMPULAN}

Terapi pencucian abses pada gajah sumatera setiap hari menggunakan $3 \% \quad \mathrm{H}_{2} \mathrm{O}_{2}$ dan iodine serta pemberian antibiotik topikal berhasil dengan baik. Kebengkakan jaringan pada gajah dewasa dan anak gajah menurun dan luka mengering (sembuh) dalam 2 minggu.

\section{- INFORMASI PENULIS}

Penulis untuk Korespondensi

*MFU: ulum@ipb.ac.id

Departemen Klinik Reproduksi dan Patologi, Fakultas Kedokteran Hewan, Institut Pertanian Bogor, Jalan Agatis Kampus IPB Dramaga Bogor Jawa Barat 16680.

\section{- PUSTAKA ACUAN}

Barman NN, Nath AJ, Sarma B. 2013. Bacterial infection, antibiogram and wound treatment in domesticated asisan elephants. Gajah. 39: 40-43.

Basha KMA, Manjunatha DR, Koppad KK. 2016. Clinical management of accute multiple abscess in a asian elephant (elephas maximus). Intas Polivet. 17(1):24.

Interchemie. 2017. Limoxin 25-spray. [internet]. Tersedia pada https://www.interchemie.com/veterinary-medicines/limoxin25-spray.html. (diakses pada tanggal 21 Januari 2018)

Setiawan D, Sibarani J, Suprihatin IE. 2013. Perbandingan efektifitas disinfektan kaporit, hidrogen peroksida, dan perekasi fenton $\left(\mathrm{H}_{2} \mathrm{O}_{2} / \mathrm{Fe}^{2+}\right)$. Cakra Kimia. 1(2): 16-24.

Sukklad S, Sommanustweechai A, Pattanarangsan R. 2006. A retrospective study of elephant wound, wound management from thai veterinarians. In: Proceedings of AZWMP. Chulalongkorn University, Faculty of Veterinary Science, Bangkok, Thailand. pp16. 